\title{
From Evidence to Imagination
}

\author{
James Lang, PhD
}

Professor of English and the Director of the D'Amour Center for Teaching Excellence Assumption University

During the final year of my PhD program, I was looking for some part-time work to supplement my graduate stipend. I saw an advertisement for a graduate fellow position at the Center for Teaching Excellence on campus, and it seemed like the number of hours was about right for me. I had no idea what a Center for Teaching Excellence was, but I sent in my application and got an interview.

The director of the center at that time was Ken Bain, a historian whose powerful and influential works-still germinating at that time-include What the Best College Teachers Do and What the Best College Students Do, two bestselling accounts of the habits and practices of highly successful faculty and their students. He offered me a job at the center. My primary duties there would include assisting in the development of programs for graduate students, helping Ken continue the research he had been conducting for What the Best College Teachers Do, and serving as a general factotum around the teaching center, assisting with whatever other projects demanded our attention. I enjoyed the work so much that when I finished my dissertation the next year, I applied for a position as assistant director, and served in that position for the next three years. ${ }^{1}$

What drew me into the work of studying teaching and learning in higher education were two things that Ken did for me, one specific and one more general. The specific thing that Ken did when I was first hired was point me to the bookshelves and file cabinets in the center, all of which were stuffed with monographs and articles on teaching and learning, and say, "Take some time and explore the library. Read around a little bit in the subjects that interest you." I was teaching as a graduate student at that time, and struggling to get students engaged in meaningful discussions of the literature they were reading, so I immediately pounced on the articles about teaching by discussion, and was thrilled to discover a host of specific new strategies I could try. ${ }^{2}$

\footnotetext{
${ }^{1}$ A longer version of this story appears in Chapter Nine of Small Teaching: Everyday Lessons from the Science of Learning, $2^{\text {nd }}$ ed., which was in press at the time of this writing.

${ }^{2}$ The first article I discovered was one whose recommendations I still use to this day: Peter Frederick's (1981) “The Dreaded Discussion: Ten Ways to Start," in Improving College and University Teaching, 29(3), 109-114.
} 
From that moment on, I got into the habit of addressing any teaching problem I might have by first digging into the literature in search of research and recommendations.

But beneath this specific invitation that Ken issued to me to explore the literature, he did something much more substantive. In his approach to faculty development, in the books he wrote and the talks he gave, in everything he did in this field, he communicated to me and to his audiences a fundamental idea that has animated my career ever since: Helping another human being learn is a fascinating challenge, one as worthy of our scholarly attention, as are the questions we pursue in our disciplines. Strange though it might seem, this had never occurred to me before. I had always walked into the classroom wondering how I was going to teach. It never occurred to me that my actual job was to help people learn. Of course once you make this mental shift, an avalanche of questions follow. How do people learn? What happens in the brain when we learn something? Why does learning fail at times and succeed at other times? Why do we forget some things we learn and remember others? What inspires people to learn, and what turns them away from learning? Questions like these have sent me continually back to the scholarship of teaching and learning in higher education throughout my career, wondering how to solve the latest problem I have encountered in my classrooms.

The body of scholarship available to help me solve such teaching problems has exploded in the past couple of decades; I doubt very much that the library of the teaching center where I began my career would be able to contain all the books that have been written on this subject since the late 1990s. That has been a welcome development, as working faculty now have access to a wide range or research on teaching and learning. In the wake of the expansion of that research has come a host of synthesizers and translators, among whom I would count myself, who are drawing from laboratory experiments on learning or new findings in brain research in order to offer practical recommendations for course design and classroom practice. Increasingly the mantra has become that our teaching should be "evidence-based." We should ensure that the teaching practices we deploy have support either from educational experiments or from a clear understanding of cognitive processes.

But while I find all of this promising in our efforts to improve our work as teachers and the learning of our students, we should remain ever alert to the possibility of the pendulum of educational thinking swinging too far in any one direction. I edit a book series on teaching and learning in higher education, and one of the things I have noticed is that the book proposals we receive tend to come in topic-related waves. For example, during the early months of the pandemic, we received multiple proposals for books on supporting students emotionally, especially in online courses. What I have been seeing more recently have been book proposals interested in exploring the development of creativity in teaching. These books are considering how teachers develop their pedagogical imaginations - how they conceive of new course designs or 
develop innovative teaching strategies for their specific contexts. While these potential authors are clearly familiar with the research on teaching and learning, they are thinking beyond it-and trying to understand how their fellow faculty can do the same.

Coming from the field of English literature, and having spent years teaching creative nonfiction writing, I think they are onto something. No matter how much evidence we might have for a specific teaching practice, every course, every classroom, and every group of students have their own unique personality. We can't apply evidence-based approaches mechanically; they always need adapting to our particular context. For that we need imagination and artfulness. My time teaching creative writing has convinced me that this is a skill people can learn and improve upon. Contrary to the tired myth that some people are just born creative, while others lack some bone or muscle of imagination, I have found repeatedly that study and practice can improve creativity just as it can improve problem-solving or test-taking skills. This applies to teachers as much as it does to students.

The act of teaching should begin with an understanding of how people learn, and the implications of that understanding for teachers. Journals like InSight are providing us with ongoing opportunities to engage with those ideas. But as the field continues to expand and evolve, we need to make sure we are validating and valorizing those teachers who are exploring and attempting radically creative new ways to teach. That can always include ideas for how to apply and adapt evidence-based practices, but it should also include strategies that push us into brand-new territories, creative techniques that might surprise ourselves and our students, and open new areas

Just as we need theorists to speak to practitioners, we need such creative practitioners to clear new ground for theorists to explore.

for future research. We tend to think about practice as deriving from theory, but reversing that direction can produce surprising new results. A creative teacher has a hunch, tries something new, finds that it resonates with her students, and then she or others seek to understand what might be underpinning its success. Just as we need theorists to speak to practitioners, we need such creative practitioners to clear new ground for theorists to explore.

I expect that any reader of this journal shares my fascination with the question of how to help another human learn. As you continue to explore the research that can help us answer this question, I encourage all of us to remember the essential role that creativity plays in our work and recognize that the practice of teaching depends at least as much upon imagination as it does upon evidence. 
James M. Lang is a Professor of English and the Director of the D'Amour Center for Teaching Excellence at Assumption University in Worcester, MA. He is the author of six books, the most recent of which are Distracted: Why Students Can't Focus and What You Can Do About It (2020), Small Teaching: Everyday Lessons from the Science of Learning (2016) and Cheating Lessons: Learning from Academic Dishonesty (2013). He writes a monthly column on teaching and learning for The Chronicle of Higher Education, and edits a book series on teaching and learning in higher education for West Virginia University Press.

"Instead of working from a deficit model-what the students lack-faculty need to embrace the unique features of their own communities of practice, helping students

to braid together their prior knowledge to construct new ways of knowing in

$$
\text { disciplinary settings" (p. 4). }
$$

Goode, J. R., Morris, K. K., Smith, B., \& Tweddle, J. C. (2021). Why aren't my students reading: Faculty \& student research unveiling the hidden curriculum of course material usage. International Journal for the Scholarship of Teaching and Learning, 15(1), Article 2. https://doi.org/10.20429/ijsotl.2021.150102 